\title{
MYH9/USP6 Fusion Gene
}

National Cancer Institute

\section{Source}

National Cancer Institute. MYH9/USP6 Fusion Gene. NCI Thesaurus. Code C121149.

A fusion gene that results from a chromosomal translocation $t(17 ; 22)(p 13 ; q 12.3-q 13)$

which fuses the promoter region of the MYH9 gene upstream of the coding region of the USP6 gene. This fusion causes increased expression of the USP6 gene and is associated with nodular fasciitis. 